\title{
Determination of Relationships between Organizational Structure Dimensions and Intellectual Capital: An Ampirical Study in Export Organizations $^{1}$
}

\author{
Mustafa BEKMEZCi \\ Prof. Dr., Toros University, \\ Faculty of Economics, Administrative and Social Sciences, \\ Department of Business Administration, \\ mustafa.bekmezci@toros.edu.tr \\ Orcid ID: https://orcid.org/0000-0002-1206-690X \\ Hüseyin YILMAZ \\ Prof. Dr., Aydın Adnan Menderes University, \\ Faculty of Economics, Department of Economics and Finance, \\ huseyin.yilmaz@adu.edu.tr \\ Orcid ID: https://orcid.org/0000-0002-3359-7670
}

\begin{abstract}
The main purpose of this research is to investigate the interaction between organizational structure dimensions and intellectual capital components. In order to achieve this aim, a comprehensive literature survey was conducted and then a set of hypotheses developed within which the conceptual model of the research was tested using data obtained from 126 exporters operating in Aydin. According to the results obtained from the study, it has been determined that organizational structure dimensions affect intellectual capital and components at different levels and significance. In the face of fierce competition, business managers should take into account the elements of centralization, hierarchical order and division of labor. Managers should also create a more agile and flexible structure and attach importance to specialization.
\end{abstract}

Keywords: Organizational Structure, Intellectual Capital, Aydın, Manufacturing Firms, Export.

\footnotetext{
${ }^{1}$ Article Arrival/Acceptance Date: 09.05.2020/11.04.2021

Reference Information: Bekmezci, M. And Yilmaz, H. (2021). Determination of relationship between organizational structure dimension and intellectual capital: An ampirical study in export organizations. Kahramanmaraş Sütçü Imam University Journal of Social Sciences, 18 (3), 1855-1886 DOI: 10.33437/ksusbd.734958.
} 


\section{Örgüt Yapısı Boyutları ve Entelektüel Sermaye Arasındaki İlişkilerin Belirlenmesi: İhracatçı İşletmelerde Ampirik Bir Çalışma}

Öz

$\mathrm{Bu}$ araştırmanın temel amacı, örgüt yapısı boyutları ile entelektüel sermaye bileşenleri arasındaki etkileşimlerin ortaya çıkarılmasıdır. Bu amaca ulaşabilmek amacıyla ilk önce kapsamlı bir literatür taraması gerçekleştirilmiş daha sonra da araştırmanın kavramsal modeli çerçevesinde geliştirilmiş bulunan hipotezler, Aydın ilinde faaliyet gösteren 126 ihracatçı işletmeden elde edilen veriler aracılığıyla test edilmiştir. Nicel araştırma yönteminin kullanıldığı çalışmadan elde edilen sonuçlara göre örgüt yapısı boyutlarının, entelektüel sermaye ve bileşenlerini farklı düzeylerde ve anlamlı bir şekilde etkilediği tespit edilmiştir. Şiddetli rekabet karşısında işletme yöneticilerinin merkezileşme, hiyerarşik düzen ve iş bölümü unsurlarını dikkate alması; daha çevik ve daha esnek bir yapı oluşturması, uzmanlaşmaya önem vermesi gerektiği sonucuna ulaşılmıştır.

Anahtar Kelimeler: Örgüt Yapısı, Entelektüel Sermaye, Aydın, İmalat İşletmeleri, İhracat.

\section{INTRODUCTION}

The organization refers to a design and structure, including a process such as determining the organizational levels, powers and responsibilities, communication and information network (Saruhan and Yildiz, 2009: 1). The structure, which emerged as a result of the design of these elements, includes authority-responsibility, communication, authority and power relations. Almost every activity in the modern world is carried out through organizations. The organization is a result of employees interacting with each other to perform basic functions that will achieve certain goals (Daft, 2015: 11). Therefore, the organization requires the existence of a purpose that people and these people cannot achieve alone, but can only achieve by working together (Tran and Tian, 2013: 229)

Many factors such as globalization, digitalization of businesses and workplaces, the necessity to respond to the needs of customers quickly, diversity of workforce, and intense competition force organizations to survive. Therefore, organizations have to rethink and redesign their structural model in accordance with changing conditions. Because the behavior of the employees is determined by the structure (Ajagbe et al., 2016: 65) and organizational structure shapes performance (Andersson and Zbirenko, 2014; Clemmer, 2003; Demir and Okan, 2009), define how efficient operational processes are (Andersson and Zbirenko, 2014). Wolf (2002), states that organizational structure has a direct impact on the 
success of the organization's operational strategy. On the other hand, Underdown (2012) states that when it is decided how the employees should behave, what behaviors are encouraged and what the employees will accomplish, the structure is formed in such a way as to reveal the desired attitudes and behaviors, and cultural values and norms are designed in accordance with the structure.

Organizations' adaptation to challenging environmental conditions, the ability to react quickly to changing customer needs, and the continuity of their existence in the environment of constant crisis and chaos called the new normal are closely related to the organizational structure. Structural form both enhances and limits what an organization can do (Bolman and Deal, 2013: 75). Organizational structure ensures efficient use of resources in the process of converting inputs into outputs, and increases the effectiveness of the organization, defined as the level of achieving its goal. Therefore, the organizational structure should be designed in accordance with the objectives, technology, workforce and environment of the organization (Bolman and Deal, 2013: 73).

Today, there is a big difference between the book value of the organizations and the market value (Saruhan and Yildız, 2009: 101; Lev, 2001: 9; Bontis, 2002: 24). This difference arises from the employees, the organization itself and the relations of the organization. The most important element that activates the structure is human. Getting the right people in the organization, giving them the right roles and appropriate responsibilities will bring success. The organization also has a memory. Therefore, the organization itself is an important factor in increasing the performance of the organization as well as the human factor. In addition, any organization is not alone in the sector in which it operates, it has other organizations and customers with whom it communicates and interacts. In this context, intellectual capital, expressed as the sum of the information in the organization originating from people, organization and relationship, has three dimensions: human, organizational/structural and relational/customer capital.

Intellectual capital, which provides competitive advantage and is determined by researches that increase the economic and financial performance of the organization, is affected by the organizational structure. In this study, the interaction between the dimensions of the organizational structure and intellectual capital has been investigated by research on exporters. Although it has been determined in the literature that there is no consensus on the dimensions of the organizational structure, in this study it is evaluated that it is the most used in researches and it is considered to be in interaction with intellectual capital; division of work and specialization, authority and responsibility equivalence, unity of command, hierarchical order, degree of centralization and communication dimensions were discussed. Exports have an important role in the economic growth of countries both in terms of earning foreign currency and 
increasing productivity. In order to be able to export and maintain exports, intellectual capital elements need to be managed better than the companies engaged in production and trade in the country.

\section{CONCEPTUAL FRAMEWORK AND LITERATURE ANALYSIS}

\section{Organizational Structure and Dimension}

The organization is a community of interconnected people, united at the disposal of a single authority, to be constantly undertaken a particular task (Ülgen, 1993: 43). As such, the organization expresses an order or arrangement, the concept of organization brings to mind the order or arrangements in the relations between work and work, work and man and man and man (Koçel, 2014: 209). Organizations are social assets geared towards specific goals, their activities are consciously structured and coordinated and linked to the external environment (Daft, 2015: 11). According to another definition, the organization is the social, economic and political structures that are consciously formed, structured, determined, and coordinated with the mutual interactions of individuals in order to achieve the specified goals (Saruhan and Yildiz, 2009: 1).

Bloisi et al. (2007: 710) defined the organizational structure as the grouping of people and tasks to increase the coordination of communication, decisions and activities. The term organizational structure refers to the formal structuring of individuals and groups, the allocation of duties, responsibilities and authority within the organization. (Ajagbe et al., 2016: 65). Stroh et al. (2002) emphasized that the organizational structure represents the relationships between the different roles played by units within an organization. Organizational structure covers the status of jobs, their relation to each other and accountability for processes and outputs of subprocesses (Tran and Tian, 2013: 230). In this context, the organizational structure can be accepted as a coordination and control tool that can guide the behavior of organizational actors towards the achievement of organizational goals (Herath, 2007: 906).

Organizational structure is the method of sharing responsibilities and power among the members of the organization and the implementation of business processes. Therefore, organizational structure includes the nature of formalization, the levels of the hierarchy, the level of horizontal integration, the centralization of authority and the patterns of communication (Ajagbe et al., 2016: 65). The first step in understanding organizations is to look at the dimensions that define specific organizational design features. These dimensions that define organizations are like the physical feature and personality used to describe people. Organizational structure is affected by many factors. Therefore, it can be shaped in many types. Aycan et al. (2016: 283) stated that there are four structural features that have important effects on employee motivation and work 
behavior. These features, which are described as comparative pairs are: (1) Specialized or general, (2) Long or straight, (3) Independent or dependent, (4) Tight or loose. The description of these features is briefly summarized below (Aycan et al., 2016: 283-284):

Specialized or general: This feature is related to the way the job is designed. There is specialization at one end. Organizations that choose to specialize design jobs with simple, repetitive movements. There is very little variety in jobs and the role of the task is very small; there is also no opportunity for initiative or creativity. On the other end, there are organizations that try to design the work as much as possible, with a variety of jobs, skills, a role in the whole task, autonomy and feedback.

Long and straight: This feature literally defines the shape of the organizational structure. There are many hierarchical levels in a long structure. This usually occurs when the control area is narrow. In a flat structure, the hierarchical level is less and this is due to the large control area. A flat structure offers employees more enriched job opportunities, while a long structure offers managers more control.

Independent or dependent: In this feature, the focus is on the independence or dependency of business units. The work of a unit can be structured either by specialization or in general. Its specialization and structuring causes more dependency. If specialization is not used, the business unit is relatively independent.

Tight or loose: It also refers to the degree of formalization within the organization. A high level of formalization makes organization a tight organization, a low level of formalization makes organization a loose organization. When describing tight and loose organizations, mechanical and organic terms are also used.

Organizational dimension can be addressed in two groups, structural and contextual (Daft, 2015: 14-15). The structural dimension provides the labels used to describe the internal characteristics of an organization. It provides a basis for analyzing and comparing organizations. Pugh et al. (1968: 72) addressed the structural dimension in six dimensions as specialization, standardization, formalization, centralization, role differentiation and traditionalism. Daft (2015: 15) states that the structural dimension includes the degree of formality, specialization, authority hierarchy, degree of centralization, professionalization and personnel rates. Germain (1996), while defining the role of context and structure in the adoption of logistic innovation, focused on specialization, decentralization and integration. Koufteros and Vonderembse (1998: 2863) stated that implementing a radical innovation such as JIT could be facilitated or 
prevented by the structural design of the organization, and stated structural design elements as centralization, formality and complexity. Santoro and Chakrabarti (2002: 1172) examined the organizational structure in three dimensions: hierarchical level, degree of formalization and degree of centralization. Zheng et al. (2010) stated that the most important components of the organizational structure are formality, centralization and control. Rapert and Wren (1998: 288) stated that the degree of centralization and formality are the most studied dimensions. Morton and $\mathrm{Hu}$ (2008) stated that the organizational structure components consist of elements such as centralization, specialization, standardization, formalism, and hierarchy. Below, the organizational structure components that are most focused on in the related literature are explained in order.

\section{Division of Work and Specialization}

The division of work refers to the distribution of tasks and is the cornerstone of the organizational structure. The degree of specialization is the level of organizational tasks divided into separate jobs (Robbins et al., 2013: 132). In other words, the grouping of activities is that the activities in each group are carried out by different employees. It is the division of the workforce (Daft, 2015: 15). It is the division of the work into very small parts (tasks) and each of these tasks is performed continuously by one person (Koçel, 2014: 216). The high level of specialization means that each employee does a small part of the job, and the low specialization means that the employees do a larger part of the job. The division of work facilitates the separation of powers and ensures that human resources are used more effectively (Keskin et al., 2016: 173). The division of work is provided in formats such as instructions, job description, operations, routines, detailed plans and rules for the work to be done.

\section{Authority and Responsibility Equivalence}

Authority is the right to place orders or instructions to others and wait for them to be followed, based on a managerial position (Robbins et al., 2013: 135). Briefly, the authority expresses the right to give orders and the power to wait for obedience to orders (Keskin et al., 2016: 173). The authority is distributed from top to bottom at organizational levels and gives managers of all levels the right to make decisions regarding their field of activity. The authority is not about the individual qualifications of the managers, but about the position they are in. Within the organizational structure, when a manager leaves his/her position, he/she loses her powers. Responsibility is the obligation to do something, to perform it, to show certain behaviors, to produce results and to account. However, the person must have authority to fulfill his/her responsibility. In other words, there should be a balance between the authority and responsibility of the 
employees. In addition, employees should not be authorized but irresponsible or unauthorized or responsible (Koçel, 2014: 259).

\section{Unity of Command}

Unity of command means that every subordinate in an organization receives orders from only one supervisor and is responsible to a supervisor (Koçel, 2014: 256). To the extent that the subordinate has a reporting relationship with a single supervisor, the orders will have less confusion and greater sense of personal responsibility. Otherwise, the subordinate is surprised at which superior orders he will follow, while the top cannot give notice what level of authority he/she has assigned to and what duties he has given. Therefore, in the organization, no subordinate should receive orders from more than one top, and each subordinate should only be bound to one top. In other words, a subordinate should not report to more than one supervisor. Therefore, the unity of command is rarely broken. The unity of command is easy to implement in classic command-type organizations. However, it is not possible to implement unity of command in command-staff, functional and modern projects and matrix type organizations (Ülgen, 1993: 59). Apart from this, the activities that the employee is responsible for and the manager to report should be clearly defined for each employee.

\section{Hierarchical Order}

Too many people work in any organization, each employee performing a certain part of fragmented work to achieve the organization's purpose. The concept of hierarchy provides an effective solution for both coordination and collaboration. The hierarchy is an effective mechanism to coordinate a complex system involving a large number of specialist units (Grant, 1996: 117). According to this mechanism, the jobs and positions in the organization should be organized in a hierarchical structure and employees should know from whom to take orders and to whom they will be responsible (Koçel, 2014: 257). In other words, authorities and responsibilities should be clearly and continuously transferred from top management to the lowest level (Ülgen, 1993: 57). Therefore, in complex organizations, there should be a hierarchy that expresses a gradual order from the highest to the lowest authority level (Keskin et al., 2016: 175). The hierarchical order is closely related to the command. The success of many organizational activities depends on rapid execution and compliance with the hierarchy.

\section{Degree of Centralization}

The degree of centralization refers to the hierarchical level of decision making authority. Centralization is the case when the decision-making authority is gathered at the upper levels of the organization (Robbins et al., 2013: 140). In 
other words, it is about the distribution of decision making authority in the organization between the levels (Koçel, 2014: 217). If the decision-making authority is gathered in the top management, the organization is centralized, and if the decision is made at the lower levels of the organization, the organization is not centralized (decentralisation) (Daft, 2015: 15). Therefore, centralization expresses "how concentrated decision making power is at the higher levels of the institution" (Caruana et al., 1998: 18; Schminke et al., 2000: 296). The traditional form of organization is in the form of a pointed pyramid, and decision-making powers are concentrated in the upper echelon (Robbins et al. 2013: 140). Senior managers who have the power to make decisions in such a structure are informed of all activities of the organization. However, when all the decisions are made by the managers and employees are asked to comply with the written rules only, the employees will not participate in decisions that may affect them and will have no impact on the activities in the workplace. Therefore, employees at lower levels will have the feeling that their control over work and workplace is restricted (Rhee, 2017: 1526).

\section{Communication}

Communication has an important place in the effectiveness and efficiency of organizational functions and is one of the most important aspects of the organization. The organization can achieve integration through its own communication system. This is the process of gathering, analyzing and reporting information so that the organization can perform its activities (Hodge et al., 2003: 44). According to Bloisi et al. (2007: 362), it is the responsibility of managers to establish top-down, bottom-up and cross-communication channels within the organization and to ensure the continuity and functionality of these channels. The main purpose of intra-organizational communication is to convey, approve, provide information and feedback, to inform, encourage and coordinate staff against changes throughout the command chain. All organizations need coordination. Ensuring coordination in the organization takes place in two ways (Hage et al., 1971: 861). The first of these is the programming and planning of each work, the implementation of these plans and programs made with the penalty and reward system, and the other is to provide continuous information flow with feedback and mutual adjustments. On the other hand, the diversity of jobs in the organization and the difference in power and status affect the degree of communication. In this context, Hage et al. (1971) found that, as a result of their research, both programmed, planned and unprogrammed and unplanned communication between departments are often affected by the complexity, formalization and centralization features of the organization. 


\section{INTELLECTUAL CAPITAL AND ITS COMPONENTS}

Intellectual capital focuses on the abstract resources of the organization that contribute to creating value (Barkat and Beh, 2018: 1) and, if it can be measured, it is considered as one of the cornerstones of providing competitive advantage. As a matter of fact, Dow Chemical has applied intellectual capital management on patents and saved 40 million dollars in tax, Skandia company has reduced its administrative expenses by $75 \%$ in the last six years with its intellectual capital measurement, has increased its productivity by $400 \%$ and Toshiba has also increased its factory productivity by $20 \%$ (Dönmez and Erol, 2016: 29-30). As a result of their research, Chen et al. (2005) determined that the intellectual capital of organizations has a positive effect on market value and financial performance and may be an indicator for future financial performance. Ozturk and Demirgunes (2007) concluded that there is a relationship between company value and intellectual capital as a result of the research conducted on 30 companies registered on the Istanbul Stock Exchange.

Today, the assets of organizations include not only tangible assets such as machinery, buildings, equipment, but also intangible assets such as management skills, know-how, patents, organizational culture and brands. Intangible assets are also among the values of the organization like concrete assets. It is emphasized that with the intellectual capital, the organization can create more value with its intangible assets instead of its tangible assets (Saruhan and Yildız, 2009: 101). Lev (2001: 9) compared the market value and book value ratio of 500 companies traded in Standards and Poors (S\&P) between 1977-2001, which increased from 1 to 5 , but $80 \%$ of these companies were reported that it does not reflect its value in its financial reports. In 1989, Charles Handy emphasized that the intellectual assets of the organization should be 3-4 times more valuable than the book value (Bontis, 2002: 24). As a matter of fact, in 1975, while $83 \%$ of the market value of the top 500 companies in USA consisted of tangible values and $17 \%$ consisted of intangible values, this situation was reversed in 2015, and the value of intangible assets reached 84\% (Demir and Erol, 2016: 30). The difference between the book value and market value of organizations is defined as intellectual capital (Brown et al., 2005: 35), the increase in this difference has increased the interest in intellectual capital. It is clear that the difference between the market value and the book value arises from intangible assets such as information, experience and relationships that do not appear in the financial statements but are promising that the organization will be successful in the future. Kaplan and Norton (2004: 4) state that $75 \%$ of the market value of American companies originates from intangible assets.

Barkat and Beh (2018: 1) defined intellectual capital as the sum of all information used by the organization to provide competitive advantage. 
Information that can be transformed into profit is intellectual capital (Pamukçu and Akarçay Öğüz, 2014: 71), Curado and Bontis (2007) stated that intellectual capital represents the accumulation of knowledge in the organization and is related to all of the information within the implicit or explicit, individual or collective organization. Suramaniam and Youndt (2005: 450) defined intellectual capital as the ability of the organization to use information resources. Therefore, it is possible to define intellectual capital as the ability to use the knowledge of the organization in a way to provide competitive advantage. Leif Edvinsson, known as the first professional intellectual capital manager, likewise treated intellectual capital as information converted into value. According to the OECD, intellectual capital is the economic value of intangible assets of an organization, in other words, human capital and structural capital (Pamukçu and Akarçay Öğ̈̈z, 2014: 70-71). Although intellectual capital is often described as intangible assets, patent rights, licensing and technology are also counted among intellectual assets and are considered visible assets of intellectual capital. In this context, intellectual capital is defined as the sum of all tangible and intangible assets that the organization has developed and accumulated over the years (Brown et al., 2005: 35; Bölükbaş1, 2014: 426). The high number of definitions reveals the importance of the subject, on the one hand, and indicates the difficulty of the definition of immaterial elements (Vidrascu, 2016: 169).

It is seen that there is no consensus on the definition of intellectual capital, but the following features are emphasized: Intellectual capital is not tangible, it is intangible. The organization has a positive effect on its financial results. It is largely related to people. It is the conversion of information into profit and provides a competitive advantage. Briefly, intellectual capital is concerned with the advantages that provide competitive advantage by creating value (Dönmez and Erol, 2016: 29) and the most valuable assets for the organization (Cortés et al., 2018: 273). The fact that intellectual capital consists of intangible assets and that these elements differ on the basis of organizations led to the development of different methods for measuring the intellectual capital. Market value book value difference and rate, Tobin's $Q$ ratio, calculated intangible value are financial methods used to measure intellectual capital (Pamukçu and Akarçay Öğ̈̈z, 2014: 73-76; Bölükbaş1, 2014: 431). Quote-weighted patents model, information accounting, DATI project and Danish Intellectual Capital Guide, Balanced Scorecard method, intellectual value added coefficient, intellectual capital index, intellectual capital-performance model, human resources accounting, intangible assets indicator, MERITUM Project, Skandia Guide, the technology broker model is the non-financial methods used to measure intellectual capital (Pamukçu and Akarçay Öğüz, 2014: 73-76).

The multiplier effect of intellectual capital in the organization is seen especially when it comes to the production of information and the renewal of 
information, which is realized through the contribution of the members of the organization that shape the knowledge step by step through its organizational learning and its competence and technical knowledge. Talents developed by human resources with the support of management in the organization enable the creation of new products and processes, which strengthens the link between intellectual capital and innovation (Cortés et al., 2018: 273-275). Indeed, Subramaniam and Youndt (2005) determined that the dimensions of intellectual capital and the interrelationships between them affect the ability of innovation as a result of longitudinal research on 93 organizations. There are also many studies showing that intellectual capital has a positive effect on economic and financial performance and efficiency (Ismail and Karem, 2011; Saengchan, 2008; Zeglat and Zigan, 2014).

The dimensions of intellectual capital have been handled and analyzed in many different ways such as human capital, relational capital, customer capital, competitive capital, social capital, supply source capital, community capital, regulatory capital, contract capital. However, there is a general approach that intellectual capital has three dimensions (Pamukçu and Akarçay Öğüz, 2014: 72; Tseng and Goo, 2005: 191; Cortés et al., 2018: 273; Edvinsson and Sullivan, 1996). These are human capital, structural capital, and relational capital. It can be said that these three dimensions include other intangible entities called by different names. Human capital is concerned with the talent, satisfaction and motivation of employees, structural capital, organizational structure, procedures, processes and managerial programs (Bontis et al., 2000), and relational capital is related to customers, suppliers and their commitment to the organization (Kim and Kumar, 2009). The dimensions of intellectual capital are described in more detail below.

\section{Human Capital}

Human capital refers to the competence of employees in the organization, namely the sum of their knowledge, skill, ability and experience, creativity and innovation ability, flexibility, job satisfaction, motivation and ability to become a team player (Vidrascu, 2016: 171). However, these competencies should be used in a way that creates value for the organization in the form of creating information, producing new products and ideas, business process or product development or improvement (Saruhan and Yildı, 2009: 102). In this context, it can be said that the main source of innovation is human capital (Bölükbaşı, 2014: 428). In its simplest form, human capital is knowledge in the minds of employees (Curado and Bontis, 2007: 320). The essence of human capital is the knowledge and intelligence of the individual. It is the cumulative sum of implicit knowledge of employees in the organization (Stovel and Bontis, 2002: 309). In this context, it can be said that education, experience, attitude and creativity are the most 
important factors for human capital. Programs, inventions, databases, methodology, documents, drawings and designs are observed activities of intellectual capital, resulting in intellectual property that provides competitive advantage to the organization, such as patents, copyrights, trademarks, and trade secrets (Vidrascu, 2016: 170).

\section{Relational Capital}

Relational capital includes the relations of the organization with its external environment, it is the sum of the relations consisting of the person or institutions that purchase the goods/services or shares of the organization (Saruhan and Y1ldiz, 2009: 104). It is also called customer capital. Every organization that has customers has customer capital. The title value of the customer capital organization is also defined as the value of its ongoing relationships with the people and organizations it sells (Stewart, 1997: 158). However, relational capital is deficient only if it is evaluated as relationships with customers. In addition to customer relations, relations with the employees in distribution channels are also important (Ergün and Yılmaz, 2012: 44). In addition, other commercial companies affecting the organization and other institutions such as the government should be evaluated within this scope. Therefore, marketing channels and customer relations information form the core of the relational capital (Bontis, 1998: 67). On the other hand, Akpinar (2002) deals with suppliers within the scope of customer capital. Relational capital has four elements: suppliers, partners, investors and customers (Ergün and Y1lmaz, 2012: 45). Therefore, relational capital consists primarily of information in non-organizational networks that have information about customers (Curando and Bontis, 2007: 320). In addition, it includes the organization's customers, suppliers, competitors and all other environmental elements with which it relates (Pamukçu and Akarçay Ögüz, 2014: 73). When evaluated within this scope, relational capital is interpersonal harmony and synergy created both within and outside the organization (Stovel and Bontis, 2002: 309).

\section{Structural Capital}

It is the intellectual capital element of the organization created by human capital and contributing to the development of human capital (Saruhan and Y1ldiz, 2009: 102). In other words, the organization itself can also have structurally implicit knowledge (Bontis, 1998: 66). In this context, structural capital includes topics such as innovation, relationship and organizational infrastructure (Chen et al., 2005: 161). It is also known as organizational capital. Daft and Weick (1984: 285) state that organizations have cognitive systems and memories, that people come and go to organizations, but that they maintain the information, behavior, mental maps, norms and values that organizations have 
over time. In other words, personal expertise and associated human capital may continue to be employed in the organization, or may leave the organization for reasons such as assignment elsewhere and employee quitting. Unlike human capital, structural capital remains in the organization and does not change easily (Walsh and Ungson, 1991: 61).

In this context, structural capital can be defined as the information that remains in the organization when the employees go to their homes. In other words, it consists of information stores located in databases, file cabinets, processes and e-mail of the organization or employees outside the human brain (Curando and Bontis, 2007: 320). As such, structural capital can be defined as the organization's effort and ability to achieve this in transforming the knowledge and experience of human capital into organizational property. Uncovering the knowledge and experience of the employees is directly proportional to the organization's opportunities. Therefore, the task of structural capital is to ensure the continuity of human capital and relational capital (Pamukçu and Akarçay Öğüz, 2014: 73).

\section{ORGANIZATIONAL STRUCTURE AND INVESTIGATION OF INTELLECTUAL CAPITAL INTERACTION}

Organizations' indispensable assets are no longer natural resources, machinery or even financial capital, but intellectual capital. In this context, it is necessary to evaluate human resources, the structure of the organization, its processes, practices and all other actors that it has relations with its customers as assets that add value to the organization. This can be achieved through the organizational structure, which is an important mechanism for coordinating communication, decisions and activities, and grouping people and tasks. Founders and top management of the organization have great responsibilities in establishing the organizational structure. There are four factors that organization founders and senior managers need to consider when creating the organizational structure (Ülgen, 1993: 129): (1) The environment in which the organization is located, (2) The size of the organization, (3) The variety of goods and services produced, (4) The thought and personality of those who set up and manage the organization.

Managers' thoughts, beliefs, assumptions and personalities play an important role in determining the interaction between the dimensions of the organization's structure and intellectual capital. In particular, the ability of managers to assume and transfer authority and responsibility, the management area, the ability to collaborate with other people or managers, the way to grow and live, personal value judgments, different behaviors and intuitions determine the structure to be established (Ülgen, 1993: 162). In this context, four important models can be 
mentioned about the beliefs and assumptions of managers (Aycan et al., 2016: 286). These are: (1) The traditional model based on the scientific management trend of Frederick Taylor (1911), (2) The model of human relations based on the work of Elton Mayo (1949) and the results of classical Hawthorne experiments, (3) Abraham Maslow (1954) and Douglas Human resources model based on McGregor's (1960) studies, (4) Human resources development model based on systems suitable for the learning organization perspective. The assumption underlying each model affects organizational design, decision making, communication, behavior control, reward and procedures for the role of the manager (Aycan et al., 2016: 286-292).

The traditional model assumes that those who work are naturally lazy, greedy, selfish and unwilling to cooperate, think that working is an unpleasant thing, tend to escape from responsibility, and the only way to deal with this is to offer material rewards to those who work. Organizational design based on this model results in a specialized, long, dependent and tight organizational structure. The human relations model is based on two assumptions. First, people have a natural need to belong, to feel useful and to be recognized. Second, if people receive a reasonable salary, it is more important than money to fulfill the natural demands set out in the first assumption. Since the human relations model implicitly accepts the assumptions of the traditional model, the organizational design using this model does not differ significantly from the organization using the traditional model.

The human resources model is based on three basic assumptions. First, if the employees have the opportunity to reach their personal goals by making a meaningful contribution to the organization's goals, he/she does not think that the work is unpleasant. Second, rising in the workplace is more important than making money. Third, most employees demand and cope with difficulty, autonomy and responsibility. Organization design is general, flat and loose. Its independent/dependent feature depends on the technology used by the organization. Jobs are indivisible and not routine. Decision making style and process are consultant and participant. There is a two-way communication between the manager and the subordinates. Access to information is free and open. It is ensured that the employees exhibit the desired behaviors, not by organizational control, but by the employee's commitment to work. Career development plans, training and development opportunities, difficult tasks are particularly important. The supervisor believes that his/her subordinates have the autonomy and self-control ability. Therefore, the manager gives autonomy and responsibility to the employees while performing their duties. As a trainer and consultant, he/she works with his subordinates, explains the roles, sets goals, provides support and feedback, eliminates the factors that hinder high performance. 
The human resources development model supports long-term learning and development to improve the business-related capacity of individuals and groups. The basic assumption applied to individuals, groups and organizations is "development by learning". Other assumptions of this approach are: (1) People have an unlimited learning and development capacity individually and collectively, (2) The primary purpose of the organization is to provide every opportunity for people and team to learn, (3) Organizations succeed when learning takes place at all levels. Employees are given importance because they are human. Organization design is general, flat and loose. Things are not divided and routine. Authorization and expertise are at the forefront in business design. It also includes "autonomous working groups". Decision making is consultant and participant. Unlimited flow of information is encouraged to facilitate the learning and adaptation processes. There is an open discussion and dialogue environment. This enables the employees to express their opinions easily, and if it is more appropriate and valid, they can easily accept the opinions and opinions of others. Employees are expected to learn themselves and have responsibility for personal development. The manager believes that subordinates want to be autonomous and control themselves and can do so. Vision is internalized by employees.

It can be seen how much difference of managers' thoughts and beliefs on organizational structure in forming the organizational structure. Intellectual capital is the information in the human, organization and the customers with which the organization is related and other institutions and the conversion of this information to benefit the organization. Therefore, this information needs to be revealed and used. This is only possible with the adoption of the human resources model and the human resources development model. In this context, upper level managers have great responsibilities in using the knowledge of the organization in a way to provide competitive advantage to the organization. The talent, teaching and leadership quality of senior managers should be used in a way that supports employees to perform their duties. Similarly, structural reforms that managers will make in the organization can help produce information.

Nonaka et al. (2000) stated that managers should provide learning environment by giving time to their employees and providing a suitable working environment, by drawing their attention, and emphasized the importance of this issue. Managers can provide a good working environment for employers, a good database that reduces working hours, and interaction opportunities to discuss organizational goals. Such structural possibilities increase information sharing. (Huang et al., 2010) and triggers innovation in the organization (Subramaniam and Youndt, 2005). The human resources model and the human resources development model also provide the knowledge and experience of the human capital to the organization. It prepares the ground for the formation of the capital of the organization in the databases, files and processes of the organization, which 
is considered as the memory of the organization. Similarly, relational capital is extremely important for the information flow of the organization (Barkat and Beh, 2018: 3). Relational capital is the information that the organization obtains through customer relations and marketing channels. As such, the relational capital covers the information that the organization obtains from people and organizations outside the organization, it gives information about which goods or services will be produced for whom, the extent of the relations with suppliers, investors, partners. Therefore, it is possible to transform this information into structural capital by adopting the human resources model and the human resources development model.

Hypotheses designed to determine the relationship between the intellectual capital dimensions of the organizational structure and the intellectual capital dimensions related to the main purpose of this study within the framework of the forecasts put forward with the literature research and explanations made so far are listed below.

H1(a,b,c,d): Organizational structure dimensions a) Division of work and Specialization, b) Degree of Centralization, c) Hierarchical Order, d) Unity of Command affects relational capital positively and significantly from intellectual capital dimensions.

H2(a,b,c,d): Organizational structure dimensions a) Division of work and Specialization, b) Degree of Centralization, c) Hierarchical Order, d) Unity of Command affects human capital positively and significantly from intellectual capital dimensions.

H3(a,b,c,d): Organizational structure dimensions a) Division of work and Specialization, b) Degree of Centralization, c) Hierarchical Order, d) Unity of Command affects structural capital positively and significantly from intellectual capital dimensions.

H4: There is a significant relationship between organizational structure and intellectual capital.

Regarding the theoretical framework and in accordance with the purpose of the research, the conceptual model of the research is summarized in Figure 1 below. 


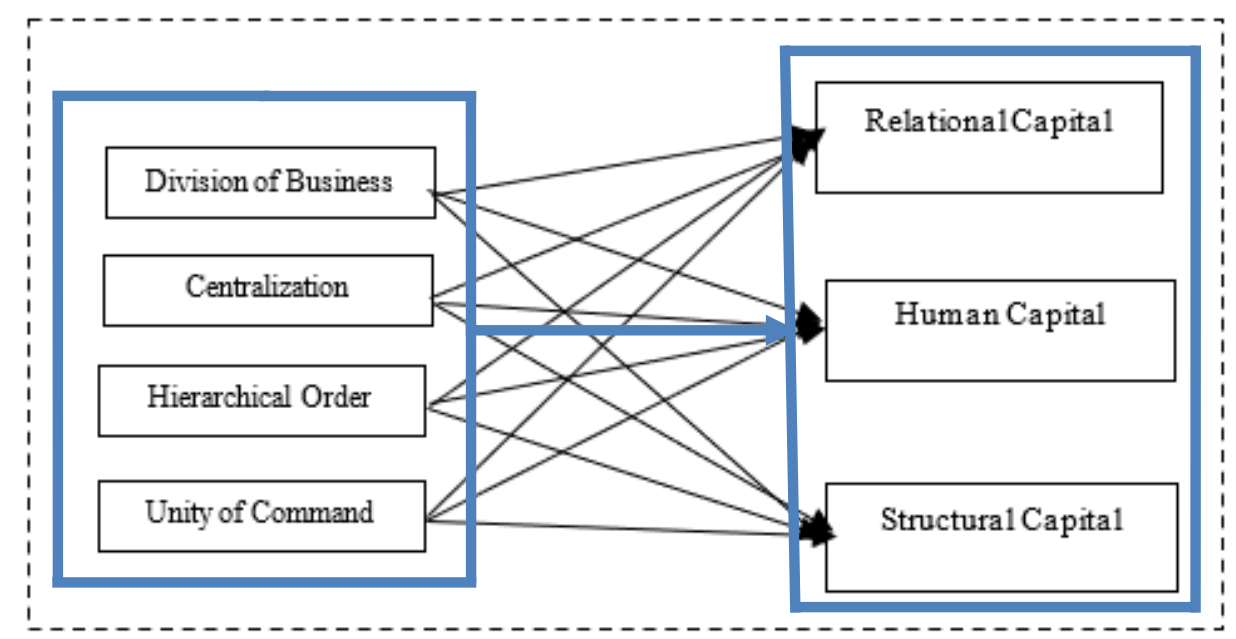

Figure 1. Conceptual Model of the Research

\section{METHOD}

\section{Sampling, Procedure and Measurement Tools}

The universe of the research is the enterprises dealing with exports in the province of Aydin in Turkey. The information about these businesses has been obtained from the official records of the Ministry of Industry. It has been determined that 274 enterprises are exporter in Aydin province. Since all of the enterprises are attainable level, a questionnaire has been sent to all of them. Questionnaire forms were tried to be filled through face-to-face interviews, but were mostly obtained by e-mail due to cost and time constraints. 135 of the questionnaire forms have returned and only 126 of them have been found ready for statistical analysis. Analyzes and results of the research are provided with these data. It was determined that the rate of return of the surveys is $49 \%$. It is seen that this rate is an acceptable rate in the literature.

In order to measure the organizational structure that expresses the independent variable of the research model developed within the scope of the study, an organizational structure measurement questionnaire, which was first developed by Jackson (2007) and later adapted to Turkish by Timurturkan (2010), was used. The scale consists of 3 dimensions and 31 questions. The "complexity" dimension was measured with 8 questions, the "centralization" dimension with 9 questions and the "formalization" dimension with 14 questions. The division of work and specialization, which are other dimensions related to the organizational structure, were measured with 10 questions, hierarchical order 2 questions and unity of command 2 questions. The scale used by Pugh et al. (1968: 65-105) was used in the preparation of the questions of this scale. The answers in the scale 
were taken with 5-point Likert (5-Strongly Agree, 4-Agree, 3-Neither agree nor disagree, 2-Disagree, 1-Strongly Disagree). The reliability coefficient of the scale was reported as Cronbach $\alpha=0.780$.

The intellectual capital scale developed and applied by Subramanian et al. (2005) was used to measure the intellectual capital, which is the dependent variable of the research. It has been determined that the relevant scale has structural, criterion and content validities. Intellectual capital scale consists of 14 items. Human capital was tried to be measured with 5 questions and social capital with 5 questions and structural capital with 4 questions. All the expressions in the scale were measured according to the 5-point Likert scale as "5-Strongly Agree, 4-Agree, 3-Neither agree nor disagree, 2-Disagree, 1-Strongly Disagree". In order to contribute to the validity and reliability of the research, reverse statements were used on the scale to control the answers of the participants. These statements were reversed before the analysis process and then included in the average and used in the analysis process (Youndt and Snell, 2004: 337-360). Information such as the duration of professional experience, age, education, position in the business, marital status and gender, which are thought to affect the organizational structure dimensions of the participants, were determined as control variables.

\section{Analysis of Data}

The data related to the sample of the study were analyzed by using SPSS 19.0 statistics program. Frequency analysis was applied to determine the demographic characteristics of the participants. Then, the reliability of the variables related to the conceptual model of the research were tested and factor analyzes were carried out to reveal which sub-dimensions they consisted of. In the next stage of the research, correlation analysis was conducted to reveal the relationships between the research variables and sub-dimensions determined by factor analysis. Finally, regression analyzes were carried out to test the hypotheses determined within the scope of the research. The demographic characteristics of the respondents in the study are shown in Table 1.

Table 1. Demographic Features of the Participants in the Research

\begin{tabular}{|c|l|c|c|}
\hline $\begin{array}{c}\text { Demographic } \\
\text { Feature }\end{array}$ & Category of Variables & $\begin{array}{c}\text { Frequency } \\
\text { Distribution }\end{array}$ & $\begin{array}{c}\text { Percentage } \\
\text { Distribution (\%) }\end{array}$ \\
\hline \multirow{3}{*}{$\begin{array}{c}\text { Professional } \\
\text { Experience } \\
\text { Time }\end{array}$} & $\mathbf{1 - 2}$ Years & 26 & 20,6 \\
\cline { 2 - 4 } & $\mathbf{3 - 5}$ Years & 37 & 29,4 \\
\cline { 2 - 4 } & $\mathbf{6 - 1 0}$ Years & 32 & 25,4 \\
\cline { 2 - 4 } & $\mathbf{1 1 - 1 5}$ Years & 8 & 6,3 \\
\cline { 2 - 4 } & $\mathbf{1 6}$ and more & 23 & 18,3 \\
\hline Age & $\mathbf{1 8 - 2 5}$ & 35 & 27,8 \\
\hline
\end{tabular}




\begin{tabular}{|c|l|c|c|}
\hline \multirow{4}{*}{} & $\mathbf{2 6 - 3 0}$ & 37 & 29,4 \\
\cline { 2 - 4 } & $\mathbf{3 1 - 4 0}$ & 24 & 19,0 \\
\cline { 2 - 4 } & $\mathbf{4 1 - 5 0}$ & 17 & 13,5 \\
\cline { 2 - 4 } & $\mathbf{5 1}$ and more & 13 & 10,3 \\
\hline \multirow{4}{*}{ Education } & Primary education & 8 & 6,3 \\
\cline { 2 - 4 } & High school & 11 & 8,7 \\
\cline { 2 - 4 } & University & 94 & 74,6 \\
\cline { 2 - 4 } & Master & 10 & 7,9 \\
\cline { 2 - 4 } & Ph.D. & 3 & 2,4 \\
\hline \multirow{4}{*}{ Marition in } & Company owner & 11 & 8,7 \\
\cline { 2 - 4 } & Company Manager & 7 & 5,6 \\
\cline { 2 - 4 } & Department Officer & 13 & 10,3 \\
\cline { 2 - 4 } & Foreman & 9 & 7,1 \\
\cline { 2 - 4 } & Employee & 86 & 68,3 \\
\hline \multirow{2}{*}{ Gender } & The married & $\mathbf{6 4}$ & $\mathbf{5 1}$ \\
\cline { 2 - 4 } & Single & $\mathbf{6 2}$ & $\mathbf{4 9}$ \\
\cline { 2 - 4 } & Woman & $\mathbf{4 3}$ \\
\cline { 2 - 4 } & Man & $\mathbf{5 7}$ & \\
\hline
\end{tabular}

\section{Descriptive Statistics for the Scales Used in the Research}

Descriptive statistics about the variables determined within the framework of the conceptual model of the research are presented in Table 2.

Table 2. Descriptive Statistics on Research Variables

\begin{tabular}{|c|c|c|c|}
\hline Operational Variable & N & Mean & Standard deviation \\
\hline Organizational Structure & 126 & 3,73 &, 570 \\
\hline (1) Division of Work & 126 & 4,08 &, 727 \\
\hline (2) Centralization & 126 & 3,60 &, 959 \\
\hline (3) Hierarchical Order & 126 & 3,63 &, 894 \\
\hline (4) Unity of Command & 126 & 3,63 & 1,00 \\
\hline Intellectual Capital & 126 & 3,89 & 1,305 \\
\hline (1) Relational Capital & 126 & 3,48 &, 983 \\
\hline (2) Human Capital & 126 & 3,87 &, 726 \\
\hline (3) Structural Capital & 126 & 4,31 & 3,36 \\
\hline
\end{tabular}

When we look closely at the findings in Table 2, where the average and standard deviation values of the measurement tools are shown, it is understood that the average of the organizational structure and dimensions, which express the independent variable of the study, varied between 3.60 and 4.08, and the standard deviation values were close to each other. When the average values of the intellectual capital and its sub-dimensions that make up the dependent variable of the research are analyzed, it is determined that the averages vary 
between 3.48 and 4.31. It is understood that the standard deviation values related to the dependent variable show affinity.

\section{Factor Analysis and Reliability}

In line with the validity and reliability analysis of the research variables, Explanatory Factor Analysis and reliability analysis were performed. As a result of the factor analysis applied to determine the structural validity of the organizational structure scale, it was determined that no question statement in the scale was below the 'Measures of Sampling Adequacy (MSA)' 0.50 in the AntiImage Correlation Matrix and was suitable for factor analysis. As a result of factor analysis on the relevant scale, 4 factors consisting of 18 expressions with Eigenvalues 1 and above were obtained $(\mathrm{KMO}=0,826$, Bartlett's Test of Sphericity Approx. Chi-Square $=954,773, \mathrm{df}=253$ ve $\mathrm{p}=0,000)$. Total explained variance was determined as $60.708 \%$. As a result of the analysis, it was understood that the scale used to measure the organizational structure does not have a different distribution from the original scale. The factors obtained with this result were named as Division of work and Specialization (Explanatory 28.939\%), Centralization (Explanatory 15.022\%), Hierarchical Order (Explanatory $8.4439 \%$ ) and Unity of Command (Explanatory $8.308 \%$ ). The reliability levels of the mentioned dimensions, which are presented within the scope of the analysis, were determined separately and in total. As a result of the analysis, it was understood that all dimensions related to the organizational structure scale were reliable (Division of Work and Specialization: Cronbach $\alpha=0,92$; Centralization: Cronbach $\alpha=0,750$; Hierarchical Order: Cronbach $\alpha=0,712$; Unity of Command: Cronbach $\alpha=0,702$ ). The results obtained when the organizational structure scale was subjected to reliability analysis in aggregate were found to be acceptable high (Cronbach $\alpha=0.844$ ). It is understood that the scale of organizational structure used in the research is a reliable measurement tool.

Within the framework of the explanatory factor analysis applied to the intellectual capital scale, it was determined that no question expression value other than just one question was found under the 'Measures of Sampling Adequacy (MSA)' below 0.50 in the Anti-Image Correlation Matrix and all of them were found to be suitable for factor analysis. As a result of the analysis applied to the scale, it was observed that there were three factors consisting of 14 expressions with Eigenvalues 1 and above $(\mathrm{KMO}=0,708$, Bartlett's Test of Sphericity Approx. Chi-Square $=846,330, \mathrm{p}=0,000$ ). Total variance was determined as $60,452 \%$. It is understood that all dimensions of the intellectual capital scale show the same distribution as the original scale. The factors obtained are named as relational capital (Explanatory 28,185\%), human capital $($ Explanatory $=21,593 \%)$ and structural capital (Explanatory=10,674\%). The 
reliability values of these dimensions obtained in the continuation of the analysis were determined separately and in total. As a result of the reliability analysis, the reliability of the mentioned dimensions was found to be at acceptable levels (relational capital: Cronbach $\alpha=0,863$; human capital: Cronbach $\alpha=0,794$; structural capital: Cronbach $\alpha=0,708)$. As a result of the reliability analysis applied collectively to all relevant dimensions, the reliability coefficient was found to be acceptable and high (Cronbach $\alpha=0,803$ ). The findings show that the intellectual capital scale, which expresses the dependent variable of the research, is a reliable scale.

The Tukey Test was conducted on the organizational structure and intellectual capital variables in the conceptual model of the research. As a result of the Tukey Test, all these variables were analyzed together with their sub-dimensions. Correlation analysis was carried out to determine the relationships among the variables within the scope of the research model. As a result of the analysis, it was determined that the research variables are related to each other. When the correlation analysis findings shown in Table 3 are evaluated, it is seen that there is a significant variety of relationships between the dimensions of the organizational structure and intellectual capital. When the relationships between the dependent and independent variables subject to analysis are analyzed at a specific level, it is seen that the variable that has the strongest relationship with the organizational structure dimensions is the hierarchical order $(r=, 397)$, and the weakest relationship is the unity of command $(\mathrm{r}=-, 204)$. When the relationship of the dimensions that make up the intellectual capital with the organizational structure is examined, it is understood that relational capital is the factor with the most relation $(r=, 507)$. It was determined that structural capital, which is one of the intellectual capital dimensions, has the weakest relationship with organizational structure $(\mathrm{r}=, 109)$. When the relationship between the organizational structure as the independent variable of the research and the intellectual capital expressing the dependent variable is closely examined, it is determined that there is a significant, positive and strong relationship between the two variables $(r=, 305)$.

Table 3. Organizational Structure Dimensions and Intellectual Capital Dimensions Correlation Matrix

\begin{tabular}{|l|c|c|c|c|c|c|c|c|c|}
\hline Factors & $\mathbf{1}$ & $\mathbf{2}$ & $\mathbf{3}$ & $\mathbf{4}$ & $\mathbf{5}$ & $\mathbf{6}$ & $\mathbf{7}$ & $\mathbf{8}$ & $\mathbf{9}$ \\
\hline $\begin{array}{l}\text { (1) Division of } \\
\text { Work }\end{array}$ & $\mathbf{1}$ &, $205^{*}$ &, $371^{* *}$ &, $184^{*}$ &, 046 &, $495^{* *}$ &, $268^{* *}$ &, $631^{* *}$ &, $333^{* *}$ \\
\hline $\begin{array}{l}\mathbf{( 2 )} \text { Centralization } \\
\text { (3) Hierarchical }\end{array}$ & & $\mathbf{1}$ &, $236^{* *}$ &, $331^{* *}$ &, $574^{* *}$ &, 105 &, 153 &, $717^{* *}$ &, $295^{* *}$ \\
\hline $\begin{array}{l}\text { Order } \\
\text { (4) Unity of } \\
\text { Command }\end{array}$ & & $\mathbf{1}$ &,- 033 &, $245^{* *}$ &, $502^{* *}$ &, $282^{* *}$ &, $582^{* *}$ &, $397^{* *}$ \\
\hline
\end{tabular}




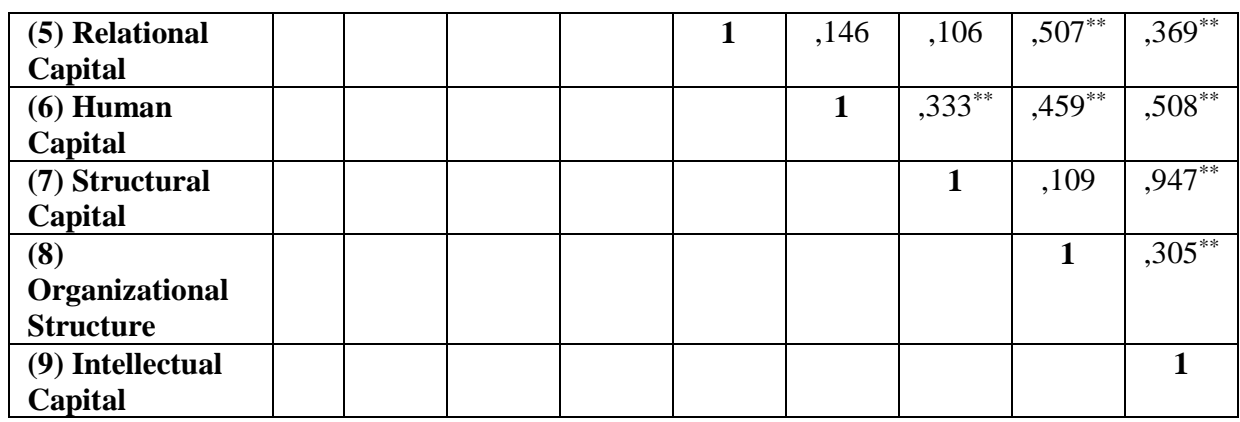

* Correlations are significant at the 0.05 level (2-tailed), ** Correlations are significant at the 0.01 level (2-tailed).

\section{Hypothesis Tests}

A regression analysis and hierarchical regression analysis were performed in order to test the hypotheses determined within the scope of the research. a) Division of work and Specialization, b) Degree of Centralization, c) Hierarchical Order, d) The Unity of Command is predicted to positively and significantly affect relational capital from the intellectual capital dimensions. Regression analysis results show that the degree of centralization $(\beta=, 502)$, hierarchical order $(\beta=, 221)$ and unity of command $(\beta=, 213)$ have a positive and significant effect on the relational component of intellectual capital. It is observed that the division of work and specialization, which is one of the organizational structure dimensions, has a negative effect on the relational dimension related to intellectual capital $(\beta=-, 178)$. It is understood that the model with three independent variables, which are found to be statistically significant, explains the effect of four dimensions of the organizational structure on the relational dimension of intellectual capital (at the level of ,000 significance) by $39.3 \%$. With this result, H1b, c, d hypotheses were confirmed and H1a hypothesis could not be confirmed $(\mathrm{p}<0.05)$.

In the second hypothesis of the research, it is predicted that "Organizational structure dimensions a) Division of work and Specialization, b) Degree of Centralization, c) Hierarchical Order, d) Unity of Command positively and significantly affect human capital from the intellectual capital dimensions." It is understood that the regression model established to test the accuracy of this hypothesis is meaningful. When the findings of the model were analyzed, it was determined that there was a positive and strong relationship between the dimensions of the organizational structure outside the degree of centralization and the human capital dimension of the intellectual capital, and the relation in question was also significant $\left(\mathrm{R}^{2}=, 374 ; \mathrm{p}=, 000\right)$. It is understood from the dimensions related to the organizational structure that the degree of centralization has a negative interaction with human capital $(\beta=-, 073)$. Organizational structure 
dimensions explain $39.4 \%$ of the total variance in human capital. In other words, the size of the organizational structure of the human capital is affected by the hierarchical order dimension $(43 \%)$, the division of work and specialization $(34 \%)$ and the unity of command $(8 \%)(\mathrm{p}<0.05)$. According to this situation, it was concluded that $\mathrm{H} 2 \mathrm{a}$, c hypotheses were supported, and $\mathrm{d}$ hypothesis was not accepted.

With the third hypothesis of the research, it is predicted that "Organizational structure dimensions a) Division of work and Specialization, b) Degree of Centralization, c) Hierarchical Order, d) Unity of Command positively and significantly affect structural capital from the intellectual capital dimensions." The results of the regression analysis applied to test this hypothesis reveal that the organizational structure dimensions, the division of work and specialization $(\beta=, 266)$, the degree of centralization $(\beta=, 225)$ and the hierarchical order $(\beta=, 113)$ are positively effective. From the findings, it was determined that the organizational structure of the unity of command dimension $(\beta=-, 466)$ negatively affected the structural capital $(\beta=-, 466 ; p<0.05)$. It was determined that the model with three independent variables explained the structural capital dimension (at the level of ,000 significance) by $27.8 \%$. In other words, when the proportional effects of organizational structure dimensions on structural capital are examined, it is seen that the division of work and specialization affects $26.6 \%$, the degree of centralization $(22.5 \%)$ and the hierarchical order in $11.3 \%(\mathrm{p}<0.05)$. As a result of the regression analysis regarding $\mathrm{H} 3 \mathrm{a}, \mathrm{b}, \mathrm{c}$ and d hypotheses, it is understood that $\mathrm{H} 3 \mathrm{c}$ hypothesis is not supported, $\mathrm{H} 3 \mathrm{a}, \mathrm{b}$ and $\mathrm{d}$ hypotheses are supported.

Another relationship tested in the research is the interaction between the organizational structure that expresses the independent variable of the research and the intellectual capital that forms the dependent variable. The statistical model established in this framework was found to be significant. According to the results of the regression model in which the effects of both variables of the research on each other as a whole were tested, it was determined that the organizational structure had a positive and significant effect on intellectual capital $(\beta=, 305, p=, 001)$. The bivariate model explains the impact of organizational structure on intellectual capital as a whole, by $9.3 \%$. With this result, $\mathrm{H} 4$ has been confirmed. Detailed findings regarding the hypothesis testing conducted within the scope of the research are shown in Table 4 below. 
Table 4. Regression Analysis Results for Testing the Effects of Organizational Structure Dimensions on Intellectual Capital Dimensions

\begin{tabular}{|c|c|c|c|c|c|c|c|c|}
\hline $\begin{array}{c}\text { Mod } \\
\text { el }\end{array}$ & Variables & $\begin{array}{c}\text { Adjusted } \\
\mathbf{R}^{\mathbf{2}}\end{array}$ & $\mathbf{F}$ & $\begin{array}{l}\text { Chang } \\
e \text { in } R^{2}\end{array}$ & $\begin{array}{l}\text { Significan } \\
\text { ce } \mathbf{F}\end{array}$ & $\begin{array}{l}\text { Standar } \\
\text { dized } \\
\text { Beta }\end{array}$ & $\begin{array}{c}\text { t } \\
\text { Value }\end{array}$ & $\begin{array}{l}\mathbf{p} \\
\text { Valu } \\
\mathbf{e}\end{array}$ \\
\hline \multirow{6}{*}{1} & \multicolumn{8}{|c|}{$\begin{array}{l}\text { H1 }(a, b, c, d): \text { Organizational structure dimensions a) Division of work and Specialization, b) } \\
\text { Degree of Centralization, c) Hierarchical Order, } d) \text { Unity of Command affect the relational } \\
\text { capital with the association of management and intellectual capital dimensions. }\end{array}$} \\
\hline & &, 393 & 21,071 &, 413 &, 000 & & & \\
\hline & $\begin{array}{r}\text { Division of } \\
\text { Work and } \\
\text { Specializatio } \\
\mathrm{n}\end{array}$ & & & & &,- 178 & $-2,301$ & ,023 \\
\hline & $\begin{array}{r}\text { Degree of } \\
\text { Centralizatio } \\
\mathrm{n}\end{array}$ & & & & & ,502 & 6,540 & ,000 \\
\hline & $\begin{array}{r}\text { Hierarchical } \\
\text { Order }\end{array}$ & & & & & ,221 & 2,844 & ,005 \\
\hline & $\begin{array}{r}\text { Unity of } \\
\text { Command }\end{array}$ & & & & & ,213 & 2,800 & ,006 \\
\hline \multirow{6}{*}{2} & \multicolumn{8}{|c|}{$\begin{array}{l}\text { H2 }(a, b, c, d): \text { Organizational structure dimensions a) Division of work and Specialization, b) } \\
\text { Degree of Centralization, } c \text { ) Hierarchical Order, } d) \text { Unity of Command affects human capital } \\
\text { positively and significantly from the intellectual capital dimensions with the unity of } \\
\text { command. }\end{array}$} \\
\hline & &, 374 & 19,531 & ,394 &, 000 & & & \\
\hline & $\begin{array}{r}\text { Division of } \\
\text { Work and } \\
\text { Specializatio } \\
n\end{array}$ & & & & & ,336 & 4,277 & ,000 \\
\hline & $\begin{array}{r}\text { Degree of } \\
\text { Centralizatio } \\
\mathrm{n}\end{array}$ & & & & &,- 073 &,- 936 & ,351 \\
\hline & $\begin{array}{r}\text { Hierarchical } \\
\text { Order } \\
\end{array}$ & & & & & ,429 & 5,433 & ,000 \\
\hline & $\begin{array}{r}\text { Unity of } \\
\text { Command }\end{array}$ & & & & & ,080 & 1,041 & ,300 \\
\hline \multirow{6}{*}{3} & \multicolumn{8}{|c|}{$\begin{array}{l}\text { H3 }(a, b, c, d) \text { : Organizational structure dimensions a) Division of work and Specialization, b) } \\
\text { Degree of Centralization, } c) \text { Hierarchical Order, } d) \text { Unity of Command affects structural } \\
\text { capital positively and significantly from the intellectual capital dimensions with the unity of } \\
\text { command. }\end{array}$} \\
\hline & & ,278 & 12,910 & ,301 & ,000 & & & \\
\hline & $\begin{array}{r}\text { Division of } \\
\text { Work and } \\
\text { Specializatio } \\
\mathrm{n}\end{array}$ & & & & & ,266 & 3,154 & ,002 \\
\hline & $\begin{array}{r}\text { Degree of } \\
\text { Centralizatio } \\
\mathrm{n}\end{array}$ & & & & & 225 & 2,687 & ,008 \\
\hline & $\begin{array}{r}\text { Hierarchical } \\
\text { Order }\end{array}$ & & & & & ,113 & 1,325 & ,188 \\
\hline & $\begin{array}{r}\text { Unity of } \\
\text { Command }\end{array}$ & & & & &,- 466 & $-5,617$ & , 000 \\
\hline & \multicolumn{8}{|c|}{ H4: There is a significant relationship between organizational structure and intellectual capital. } \\
\hline 4 & $\begin{array}{l}\text { Organization } \\
\text { al Structure }\end{array}$ & ,086 & 12,605 & ,093 & ,001 & ,305 & 3,550 & ,001 \\
\hline
\end{tabular}




\section{CONCLUSION AND EVALUATION}

Factors such as economic fluctuations, developments in technology, and increasing competition require that organizational structure and intellectual capital be compatible. Organizations' ability to continue their existence requires them to turn to products, processes and markets different from their competitors. It is understood that the companies that develop product architecture that can not be easily imitated in a short period of time by competitors are prominent with their financial and market performances. Intellectual capital is at the base of differentiation. It has become a rule that almost every business can easily imitate all their assets other than their intellectual assets in a short time and easily. The fact that intellectual capital cannot be imitated and the information assets have an increasing value brings the opportunity for organizations to increase the market value to a value in front of competitors. Organizational structure emerges as an operational factor in ensuring the supply of resources for production towards target markets, strict adherence to the competitive environment, and exhibiting motivation and effective coordination in order to achieve the objectives. Exploring the interaction between organizational structure and intellectual capital, conducting analysis on the link between the organizational structure's output and developments in intellectual capital quality will bring new perspectives on competition and value to businesses.

In this study, the findings regarding the examination of the relations between organizational structure and intellectual capital revealed that there are statistically significant and strong relationships between organizational structure and intellectual capital. When the relationships between the mentioned variables of the research are evaluated; there is a significant relationship between organizational structure dimensions (division of work and specialization, centralization, hierarchy, unity of command) and the relational capital dimension of intellectual capital; there is a significant relationship between organizational structure dimensions, division of work and specialization and hierarchy, and intellectual capital dimensions with human capital, but there is no significant relationship between centralization and unity of command; it has been determined that there is a significant relationship between organizational structure dimensions, division of work and specialization, centralization and unity of command, but there is no significant relationship between hierarchy.

When the relationships between the mentioned variables of the research were evaluated, it was determined that the degree of centralization among the organizational structure dimensions was the most influential variable on relational capital $(\beta=, 502 ; p<0.05)$. Considering that relational capital includes the elements of the organization's immediate business environment, it can be concluded that a decentralized organization model cannot focus sufficiently, and 
that the decentralized model of the organization, in which decisions, authority and power are transferred to lower levels, will make the expected contribution to the relational component of intellectual capital. In the research, it was understood that hierarchical order and unity of command factors also had an effect on relational capital $(\beta=, 221>, 213 ; \mathrm{p}<0.05)$.

Another finding put forward within the scope of the study was the level of influence of the organizational structure of intellectual capital on human capital. As a result of the hierarchical regression analysis applied in relation to this, it was determined that the hierarchical order component of the organizational structure was the most influential factor in human capital $(\beta=, 429 ; p<0.05)$. Considering that human capital is the most valuable asset of the organization, it is understood that the hierarchy, which is the key of coordination and cooperation in the high performance of the organization, is shaping the human capital. Employees are influenced by the structure with the knowledge they have, the behaviors they exhibit and their experiences regarding the information infrastructure of the organization. Therefore, it is understood that the fact that the organizational structure is in a vertical, authoritative plane affects human capital negatively, while the structure based on the team and giving priority to strengthening will support the outputs of human capital more.

Another result obtained in the scope of the research is that the division of work and specialization among organizational structure dimensions is the variable that affects the structural dimension of intellectual capital the most. The hierarchical regression analysis conducted in this framework determined that the factors affecting structural capital are the division of work and specialization, degree of centralization and hierarchical order, respectively $(\beta=, 266>, 225>113 ; p<0.05)$. This reveals that the primary component of the organizational structure created by human capital of the organization, which determines the development of employees and the success of the innovation process, is the division of work and specialization. It is understood that structural capital is strongly influenced by the degree of specialization, given that the degree of specialization is the practice of dividing the workforce by dividing the workforce into certain jobs by structuring each work into certain tasks by dividing the workforce into sections. Based on the findings and explanations, it is possible to conclude that the structural capital of an organization will be adversely affected as the division of work and degree of specialization of the organization increases, and structural capital will strengthen as the division of work and specialization is directed towards flexible specialization, business expansion and business enrichment.

The study attempted to deal with the relationships between operational variables as a whole. According to the result of the regression analysis performed for this purpose and the standardized beta coefficient obtained, it has been 
determined that the organizational structure has a strong and positive effect on intellectual capital $(\beta=, 305 ; p<0.05)$. This result shows that the organizational structure is a decisive factor in making a difference in the competition for the business. It is understood that the structure has a strategic importance for optimizing the intellectual capital performance. Enterprises should be able to shape their organizational structure components according to developments in the external environment, and prefer structural features that emphasize looser, flexible specialization, delegation, communication and coordination during periods of increased competition. Today's fierce competition conditions highlight an organizational structure that attaches importance to harmony and differentiation, the main source of differentiation is determined as intellectual capital, and the success of businesses depends on demonstrating the ability to blend the components of the structure and intellectual capital optimally. It can be said that these findings are compatible with the literatüre (Cortés vd., 2018; Zéghal \& Maaloul, 2010; Ismail \& Karem, 2011; Saengchan, 2008; Zeglat \& Zigan, 2014).

Finally, the contribution of this research to the literature can be expressed as addressing the effects of organizational structure on intellectual capital in a holistic model, analyzing the relationships between the variables in the model for the first time and eliminating a theoretical gap. The contribution of research applications in a business environment of the effects of the intellectual capital of the organization structure of the component to be revealed by analysis of perceptions and employees are subjected to testing in this case for the first time in Turkey.

As a result, the research has some limitations at the theoretical, conceptual and methodological levels, but reveals results that are relational in terms of literature and guiding for practitioners. Furthermore, in order to examine the subject of the research more comprehensively, it is suggested to carry out a specific analysis on larger samples in the future studies.

\section{REFERENCES}

Ajagbe, M. A., Cho, N. M. Udo, E. Edem U. and Peter, O. F. (2016). How organizational structure aids business performance. International Journal of Research in Commerce \& Management, 7(8) 64-68.

Akpınar, S. (2002). Entelektüel Sermaye Yönetimi ve Bir Boya İşletmesi Üzerine Etkileri I. Ulusal Bilgi, Ekonomi ve Yönetim Kongresi, Kocaeli, 727-739.

Andersson, J. and Zbirenko, A. (2014). Effect of organizational structure, leadership and communication on efficiencyand productivity-a qualitative 
study of a public health-care organization, Bachelor Thesis, Umeä Universitet.

Aycan, Z.; Kanungo, R. N. and Mendonça, M. (2016). Kültürler arası bağlamda örgütler ve yönetim, KÜY.

Barkat, W. and Beh, L.-S. (2018). Impact of intellectual capital on organizational performance: Evidence from a developing country. Academy of Strategic Management Journal, 17(2), 1-8.

Bloisi, W., Cook, C. W. and Hunsaker, P. L. (2007) Management and organizational behaviour, 2nd ed., McGraw-Hill, Maidenhead.

Bolman, L.G. and Deal, T. E. (2013). Organizasyonlart yeniden yapılandırmak, (Çev. Ahmet Aypay ve Abdurrahman Tanrı̈ögen), Seçkin.

Bontis, N. (1998). Intellectual capital: An exploratory study that develops measures and models" Management Decision, 36(2), 63-76.

Bontis, N.; Keow, William C. C. and Richardson, S. (2000). Intellectual capital and business performance in Malaysian industries, Journal of Intellectual Capital, 1(1), 85-100.

Bontis, N. (2002). The rising star of the chief knowledge officer, Ivey Business Journal, 66(4), 20-25.

Bontis, N. (1998). Intellectual capital: An exploratory study that develops measures and model, Management Decision, 36(2), 63-76.

Bölükbaşı, Y. (2014). Entelektüel sermayenin işletme bazında ölçülmesinde kullanılan yöntemler ve sigorta sektöründe bir araştırma. Marmara Üniversitesi İ.I.B. Dergisi, 36(1), 425-447.

Brown, Jr., A. Osborn, T., Chan, J. M. and Jaganathan, V. (2005). Managing intellectual capital. Research Technology Management, 48(6), 34-41.

Caruana, A., Morris, M. H., and Vella, A. J. (1998). The efect of centralization and formalization on entrepreneurship in export firms. Journal of Small Business Management, 36(1), 16-29.

Chen, M.-C., Cheng, S.-J. and Hwang, Y. (2005). An empirical investigation of the relationship between intellectual capital and firms market value and financial performance. Journal of Intellectual Capital, 6(2), 159-176. 
Clemmer, J. (2003). Organization structure limits or liberates high performance. https://www.clemmergroup.com/articles/ organization-structure-limitsliberates-high-performance/ (10.02.2018).

Cortés, E. C., Sáez, P. Z. and Illescas, M. G. (2018), Intellectual capital management: An approach to organizational practices in ecuador. Intangible Capital, 14(2), 270-285.

Curando, C. and Bontis, N. (2007). Managing Intellectual Capital: the MIC Matrix. International Journal of Knowledge and Learning, 3(2/3), 316328.

Daft, R. L. and Weick, K. E. (1984). Toward a model of organizations as interpretation systems. The Academy of Management Review, 9(2), 284295.

Daft, R. L. (2015). Örgüt kuramları ve tasarımlarını anlamak, (Cev. Ed. Ömür N. Timurcanday Özmen), Nobel Yayıncılık.

Demir, H. and Okan, T. (2009). Teknoloji, örgüt yapısı ve performans arasındaki ilişkiler üzerine bir araştırma. Doğuş Üniversitesi Dergisi, 10(1), 57-72.

Dönmez, A. and Erol, İ. (2016). Entelektüel sermayenin ölçülmesi: varc yöntemi yardımıyla BIST Sürdürülebilirlik Endeksi işletmeleri üzerine bir uygulama, Mali Çözüm, Kasım-Aralık, 27-56.

Edvinsson, L. and Sullivan, P. (1996). Developing a model for managing intellectual capital. European Management Journal, 14(4), 356-364.

Ergün, E. and Y1lmaz, O. (2012). The effects of the relation level of relational capital and structural capital on the intellectual capital level and firm's fnancial and nonfinacial performance. IIB International Refereed Academic Social Sciences Journal, 03(08), 39-58.

Germain, R. (1996). The role of context and structure in radical and incremental logistics innovation adoption. Journal of Business Research, 35(2), 117127.

Grant, R. M. (1996). Toward a knowledge-based theory of the firm. Strategic Management Journal, 17, 109-122.

Hage, J. Aiken, M. and Marrett, C. B. (1971). Organization structure and communications. American Social Review, 36(5), 860-871. 
Herath, S. K. (2007). A Framework for management control research. Journal of Management Development, 26(9). 895-915.

Hodge, B. J., Anthony, W. P. and Gales, L. M. (2003). Organization theory. 6th ed., Prentice Hall, New Jersey.

Huang, Y. C. and Wu, Yen C. J. (2010). Intellectual ccapital and knowledge productivity: The Taiwan biotech industry. Management Decision, 48(4), 580-599.

Ismail, K. N., Izah K. and Al-Musali, M. A. K. (2011). Intellectual capital and finacial performance of banks in Bahrain. Journal of Business Management and Accounting, 1(1), 63-77.

Jackson, J. M. (2007). An examination of the relationship between elementary school principles perceptions of shared decision making and three organizational structures, dissertation, UMI Number: 3279738, 2007, 68 87.

Kaplan, R. S. and Norton, D. P. (2004). Strategy maps: Converting intangible assets into tangible outcomes, Harvard Business School Press, Boston.

Keskin, H. Akgün, A. E. and Koçoğlu, İ. (2016). Örgüt teorisi, Nobel Yayınc1lık

Kim, D.-Y. and Kumar, V. (2009). A framework for prioritization of intellectual capital indicators in R\&D. Journal of Intellectual Capital, 10(2), 277-293.

Koçel, T. (2014). İsletme yöneticiliği, 15.b., Beta Yayıncılık.

Koufteros, X. A. and Vonderembse, M. A. (1998). The impact of organizational structure on the level of jit attainment: Towards theory development. International Journal of Production Research, 36(10), 2863-2878.

Lev, B. (2001). Intangibles: management and reporting, Brookings Institution Press, Washington, DC.

Morton, N. A. and Hu, Q. (2008). Implications of the fit between organizational structure and ERP: A structural contingency theory perspective" International Journal of Information Management, 28(5), 391-402.

Nonaka, I., Toyama, R. and Konno, N. (2000). SECI, Ba and leadership: A unified model of dynamic knowledge creation. Long Range Planning, 33(1), 5-34. 
Özturk, M. B. and Demirgunes, K. (2007). Determination of effect of intellectual capital on firm value via value added intellectual coefficient methodology: an emprical study on ISE-Listed manufacturing firms. Istanbul Stock Exchange Review, 10(37), 59-78.

Pamukçu, A. and Akarçay Öğüz, A. (2014). Firma değerlemesinde entelektüel sermayenin yeri ve önemi. Marmara Üniversitesi Öneri Dergisi, 11(42), 69-87.

Pugh, D. S., Hickson, D. J., Hinings, C. R. and Turner, C. (1968). Dimensions of organization structure. Administrative Science Quarterly, 13(1), 65-105.

Rapert M. I. and Wren B. M. (1998). Reconsidering organizational structure: A dual perspective of frameworks and processes. Journal of Managerial Issues, 10(3), 287-302.

Rhee, J., Seog, S. D., Bozorov, F. and Dedahanov, A. T. (2017). Organizational structure and employees' innovative behavior: The mediating role of empowerment. Social Behavior and Personality, 45(9), 1523-1536.

Robbins, S. P.; Decenzo, D. A. and Coulter, M. (2013). Yönetimin esasları, (Çev. Ed.: Adem Öğüt), Nobel Yayıncılık.

Saengchan, S. (2008). The role of intellectual capital in creating value in the banking industry. International Review of Business Research, 7(2), 157169.

Santoro, M. D. and Chakrabarti, A. K. (2002). Firm size and technology centrality in industry-university interactions. Research Policy, 31(7), 1163-1180.

Saruhan, S. C. and Yıldız, M. L. (2009). Çağdaş yönetim bilimi, Beta Yayıncılık

Schminke, M., Ambrose, M. L. and Cropanzano, R. S. (2000). The effect of organizational structure on perceptionsof procedural fairness. Journal of Applied Psychology, 85(2), 294-304.

Stewart, T. A. (1997), Entelektüel sermaye, (Çev.: Nurettin Elhüseyni), MESS.

Stovel, M. and Bontis, N. (2002). Voluntary turnover: Knowledge managementfriend or foe?. Journal of Intellectual Capital, 3(3), 303-322.

Stroh, L. K.; Northcraft, G. B. and Neale, M. A. (2002). Organizational behavior: A management challenge, Mahwah, N.J, Lawrence Erlbau. 
Subramaniam, M. and Youndt, M. A. (2005). The influence of intelectual capital on the types of innovative capabilities. Academy of Management journal, 48(3), 450-463.

Timurturkan, K. (2010). Örgütsel yapının örgütsel değişime direnç üzerindeki etkisi: İzmir tapu ve kadastro bölge müdürlüğ̈̈’nde bir uygulama, Doktora Tezi, Dokuz Eylül Üniversitesi.

Tran, Q. and Tian, Y. (2013). Organizational Structure: Influencing Factors and Impact on a Firm. American Journal of Industrial and Business Management, 3, 229-236.

Tseng, C.-Y. and Goo, Y. J. (2005). Intellectual capital and corporate value in an emerging economy: empirical study of Taiwanese manufacturers. $R \& D$ Management Journal, 35(2), 187-201.

Underdown, R. (2012). Organizational structures. http://dept.lamar.edu/industrial/underdown/org_mana/org/org_structureGeorge.html (13.05.2018)

Ülgen, H. (1993), İsletmelerde organizasyon ilkeleri ve uygulaması, 2.b., İ.Ü. İşletme Fakültesi Yayın No: 258.

Walsh, J. P. and Ungson, G. R. (1991). Organizational memory. Academy of Management Review, 16(1), 57-91.

Wolf, D. (2002). Execution and structure. http://www.dewarsloan.com/workin\%20papersexecution\%20and20\%structure.html (13.05.2020).

Vidrascu, P. A. (2016), Intellectual capital, an intangible item not reflected in the finacial statements of the organizational structure. Internal Auditing \& Risk Management, 2(42), 169-177.

Youndt M. A. and Snell S. A. (2004). Human resource management, intellectual capital, and organizational performance. Journal of Managerial Issues, 16(3), 337-360.

Zeglat, D. and Zigan, K. (2014). Intellectual capitaland its impact on business performance: Evidences from the jordanian hotel industry. Tourism and Hospitality Research, 13(2), 83-100.

Zheng, W., Yang, B. and Mclean, G. N. (2010). Linking organizational culture, structure, strategy, and organizational effectiveness: Mediating role of knowledge management. Journal of Business Research, 63, 763-771. 